\title{
Monsoonal influence on seasonal variations in nutrients and phytoplankton biomass in coastal waters of Hong Kong in the vicinity of the Pearl River estuary
}

\author{
Kedong Yin ${ }^{1,2,3, *}$ \\ ${ }^{1}$ Department of Biology and ${ }^{2}$ Atmospheric, Marine and Coastal Environment (AMCE) Program, \\ Hong Kong University of Science and Technology, Clear Water Bay, Kowloon, Hong Kong SAR, PR China \\ ${ }^{3}$ LED, South China Sea Institute of Oceanology, Chinese Academy of Sciences, 164 West Xingang Road, Guangzhou 510301, PR China
}

\begin{abstract}
Some estuarine ecosystems appear to be more resistant to eutrophication than others, but the mechanisms are not well understood. The Pearl River is the second largest river in China and little is known about the long-term nutrient enrichment processes in the Pearl River estuary and adjacent coastal waters of Hong Kong. Seasonal monsoons are a climatic feature of tropical and subtropical regions. However, monsoonal influences on seasonal dynamics of nutrients and phytoplankton biomass have been little studied. This is the first report of such a study using time series of water quality data at stations around Hong Kong from 1991 to 2000. There was a strong seasonality and spatial gradient in salinity, nutrients and phytoplankton biomass around Hong Kong waters. In winter, when the NE monsoon prevailed (winds were stronger), coastal waters and the eastern part of the Pearl River estuary were dominated by high salinities ( $>30$ ) low nutrients and low phytoplankton biomass. In summer, the coastal plume from the Pearl River estuary on the west moved across the southern waters of Hong Kong to the eastern waters of Hong Kong, as the SW monsoon (winds were weaker) dominated and the Pearl River discharge was maximal. Concentrations of nitrate were high $(>60 \mu \mathrm{M})$ during summer in the Pearl River estuary, decreased $(<30 \mu \mathrm{M})$ in the coastal plume south of Hong Kong and were low $(<10 \mu \mathrm{M})$ in the eastern waters. Chlorophyll $a(\mathrm{chl} a)$ concentrations were low, high and low, respectively, in the corresponding waters. Because $\mathrm{PO}_{4}$ concentrations were low $(<1 \mu \mathrm{M})$ in all waters, nutrient ratios of $\mathrm{N}: \mathrm{P}$ and $\mathrm{N}: \mathrm{Si}\left(\mathrm{N}=\right.$ total inorganic nitrogen, $\left.\mathrm{P}=\mathrm{PO}_{4}\right)$ displayed seasonal and spatial changes. In winter, N:P and N:Si were low (near or $<16: 1$ and 1:1, respectively). In summer, however, the N:P ratio increased markedly (>64:1) in the southern waters of Hong Kong and was even higher than in the estuary. Low chl a relative to high $\mathrm{N}$ concentrations suggests that the eutrophication effect is not as severe as one would expect from $\mathrm{N}$ over enrichment. These results suggest an important role of $\mathrm{P}$ limitation in controlling phytoplankton biomass production. It appears that seasonal monsoons serve as a flushing mechanism in 2 ways: (1) monsoons reduce seasonal eutrophication effects by nutrient enrichment during summer; and (2) they prevent long-term (yr) accumulation of organic matter in the sediments due to nutrient enrichment in the region. In summer, when coastal upwelling resulting from the SW monsoon causes offshore movement of the coastal plume in the surface layer, the continental shelf oceanic waters moving shoreward at the bottom flush the coastal waters. In winter, coastal waters with low nutrients replace the entire coastal water of Hong Kong. Due to the monsoon-influenced processes and low phosphorus in the Pearl River estuary, the Pearl River estuary and adjacent coastal waters of Hong Kong appear to be more resilient to enrichment of $\mathrm{N}$.
\end{abstract}

KEY WORDS: Monsoons $\cdot$ Seasonal $\cdot \mathrm{N}$ enrichment $\cdot \mathrm{P}$ limitation $\cdot$ Pearl River estuary $\cdot$ Eutrophication $\cdot$ Nutrients $\cdot$ Phytoplankton biomass

\section{INTRODUCTION}

Eutrophication is a major concern in coastal waters, particularly in the vicinity of estuaries, where there

*Email: kyin@ust.hk has been a significant increase in nutrient input from rivers (NRC 2000, Cloern 2001). The increased input of nutrients into the coastal waters has a number of ecologi-cal consequences: increased primary productivity, a change in phytoplankton species composition (Jickell 1998) and the sedimentation of unused organic

(ㄷ) Inter-Research $2002 \cdot$ www.int-res.com 
matter which leads to low-oxygen waters, such as hypoxia or anoxia, as stratification develops (Malone et al. 1988, Cooper \& Brush 1991, Welsh \& Eller 1991). In the Gulf of Mexico, the 'dead water' in the summer covers an area of $1000 \mathrm{~s}$ of $\mathrm{km}^{2}$ due to the input of nutrients upstream in the Mississippi River (Rabalais et al. 1994, Malakoff 1998). Hypoxia is also an annual event in the Chesapeake Bay (Cooper \& Brush 1991) and Long Island Sound (Parker \& O'Reilly 1991). Accompanying the increase in nutrient loading is a change in input nutrient ratios. Usually, ratios of nitrogen $(\mathrm{N})$ to other nutrients, such as phosphorus (P) and silicon ( $\mathrm{Si}$ ), increase due to high $\mathrm{N}$ in fertilizers and in rainfall (Duce et al. 1991). There is evidence that the changes in the nutrient ratios have altered phytoplankton species composition in coastal waters (Jickells 1998). For example, the increasing abundance of $N$ and $\mathrm{P}$ relative to $\mathrm{Si}$ has resulted in displacement of diatoms by other phytoplankton species, including coccolithophores and flagellates in the Black Sea (Humborg et al. 1997), and by flagellates in the southern North Sea where the nuisance alga Phaeocystis now blooms regularly due to shifts in nutrient ratios in addition to elevated nutrient concentrations (Cadee \& Hegeman 1986, Riegman et al. 1992).

In spite of nutrient enrichment in estuaries, there is considerable uncertainty about how nutrient enrichment leads to ecosystem change in the coastal zone (Cloern 1996). Some estuaries appear to be more resilient than others. For example, San Francisco Bay does not show obvious symptoms of nutrient enrichment (Cloern 2001). A comprehensive study on the eutrophication status of estuaries in the United States revealed that the scale, intensity and impact of eutrophication may vary widely, and that the level of nutrient inputs required to produce the symptoms also varies, although nearly all estuarine waters now exhibit some symptoms of eutrophication (Bricker et al. 1999). An estuarine ecosystem may behave like a filter that dampens responses to nutrient enrichment (Cloern 2001). Many factors contribute to the buffering capacity of the filter, which is related to the susceptibility of the estuarine ecosystem to nutrient enrichment. One of the most important factors appears to be the exchange of water with the open ocean (Jickels 1998, NRC 2000, Cloern 2001). When the estuarine water is frequently exchanged with the open ocean, the estuarine ecosystem appears to be more resistant to nutrient overenrichment, whereas estuaries with low exchange rates seem to be particularly vulnerable, and the most limiting nutrient to the coastal ecosystem may become an important controlling mechanism.

The Pearl River estuary is situated on the south coast of China just west of Hong Kong and connects to the northern part of the South China Sea. The Pearl River is the second largest river in China, behind the Yangtze River, and it is ranked as the 13th in the world in terms of discharge. The Pearl River stretches for $2214 \mathrm{~km}$ and drains an area of $452000 \mathrm{~km}^{2}$ (Zhao 1990). The Pearl River flows into the Pearl River estuary through 8 entrances, 4 of which enter the Ling Ding Yang estuary, a sub-estuary of the Pearl River estuary, between Hong Kong and Macao (see Fig. 1). The annual average river discharge is $10524 \mathrm{~m}^{3} \mathrm{~s}^{-1}$, with $20 \%$ occurring during the dry season in October to March and $80 \%$ during the wet season in April to September (Zhao 1990). The Pearl River Delta region has become one of the most developed regions in China in recent years. The region, including Hong Kong, has 26.5 million inhabitants and many primary and secondary industries. The Pearl River receives a high load of anthropogenic nutrients from increased activities in agriculture (Neller \& Lam 1994), fish dike farming (Ruddle \& Zhong 1988) and sewage effluents (Hills et al. 1998) due to the population increase and economic development in southern China and the Pearl River delta region (Lin 1997).

As the population grows in the Pearl River delta region, nutrient enrichment and eutrophication symptoms should be expected in the Pearl River estuary and the waters around Hong Kong. The Hong Kong government is considering biological removal of nutrients from domestic sewage effluents, which was reviewed by an international review panel in November 2000 (IRP 2000, available at www.info.gov.hk/ssds.review). IRP (2000) considered only the removal of N using biological aerated filters technology. However, there is evidence that indicates $\mathrm{P}$ limitation occurs in waters around Hong Kong in summer (Yin et al. 2000, 2001). Therefore, determining whether $\mathrm{N}$ or $\mathrm{P}$ limits phytoplankton biomass production is a critical issue in planning sewage treatment strategy for coastal managers in Hong Kong. The South China Sea covers tropical and subtropical latitudes, and is an oligotrophic ocean. There is an exchange of waters between South China Sea and coastal waters of Hong Kong and the Pearl River estuary. The exchange is subject to monsoons and the Pearl River discharge. Little is known about monsoonal influences on variations and processes of nutrient enrichment as well as nutrient ratios in the Pearl River estuary and adjacent waters.

In this study, a $10 \mathrm{yr}$ time series of nutrients and other parameters are presented from 6 stations around Hong Kong from the Pearl River Estuary across southern waters of Hong Kong to the east side of Hong Kong. The objectives of this study were: (1) to characterize the temporal and spatial distribution of nutrients and nutrient ratios; (2) to determine whether there is any trend in nutrient enrichment in the coastal waters of Hong Kong; and (3) to examine how the spatial and 
temporal distribution of nutrients is related to monsoons and the Pearl River discharge.

\section{MATERIALS AND METHODS}

The Environmental Protection Department of the Hong Kong government has maintained a comprehensive sampling program to monitor water quality in the territorial waters for over $10 \mathrm{yr}$. There are 86 monitoring stations covering marine territorial waters of Hong Kong (EPD 1999). In this study, 5 stations representing different geographical regions were selected. They were located in the Pearl River Estuary (NM6), in southern Hong Kong (SM17 and SM19) and in SE (MM11) and NE waters (MM4) (Fig. 1). Therefore, these 5 stations are representative of the estuarine influence (NM6), the coastal plume (SM17 and SM19) and oceanic conditions (MM11 and MM4). Monthly or bi-monthly cruises were conducted on the government vessel 'Dr. Catherine Lam'. A SEACAT19 CTD was used to take vertical profiles of salinity, temperature and other parameters. Water samples were taken using the CTD rosette at 3 depths: surface, middle and bottom ( $1 \mathrm{~m}$ above the bottom) for chlorophyll a (chl a) and nutrients $\left(\mathrm{NO}_{3}, \mathrm{NH}_{4}, \mathrm{PO}_{4}\right.$ and $\left.\mathrm{SiO}_{4}\right)$. If the water depth was less than 4 to $5 \mathrm{~m}$, the middle depth was omitted. The analytical methods followed the standard

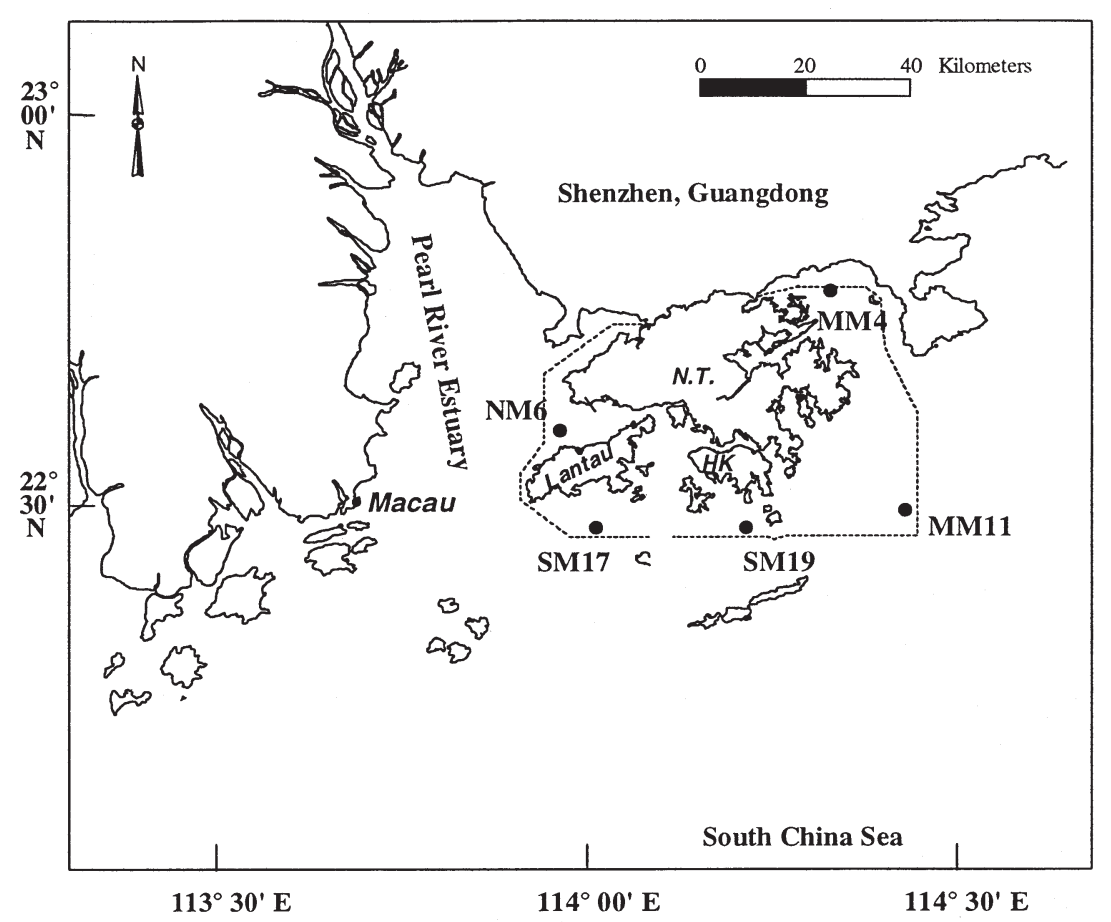

Fig. 1. Pearl River estuary and Hong Kong and the location of the sampling stations. Water quality at 5 stations (NM6, SM17, SM19, MM11 and MM4) are regularly monitored by the Environmental Protection Department, Hong Kong methods for the examination of water and wastewater, and are given in the Marine Water Quality Report, Hong Kong (EPD 1999). Basically, chl a was extracted using acetone and measured spectrophotometrically (APHA 1995, cf. EPD 1999). $\mathrm{NO}_{3}$ and $\mathrm{NH}_{4}$ were analyzed by the $\mathrm{Cu}-\mathrm{Cd}$ column reduction method (APHA 1995, cf. EPD 1999) and the indophenol blue color formation, respectively (ASTM 1991, cf. EPD 1999). Soluble $\mathrm{PO}_{4}$ (orthophosphate) was measured using the ascorbic acid method (ASTM 1991, cf. EPD 1999), and $\mathrm{SiO}_{4}$ was analyzed using molybdate, oxalic acid and a reducing reagent (APHA 1991, cf. EPD 1999). $\mathrm{NO}_{3}+$ $\mathrm{NH}_{4}$ and $\mathrm{PO}_{4}$ and $\mathrm{SiO}_{4}$ were used to calculate ratios of $\mathrm{N}: \mathrm{P}$ and $\mathrm{N}: \mathrm{Si}$.

Data for each sampling month were grouped together from different years and were averaged to obtain multi-years averages of salinity, chl $a, \mathrm{NO}_{3}+$ $\mathrm{NH}_{4}, \mathrm{SiO}_{4}, \mathrm{~N}: \mathrm{P}$ and N:Si ratios. The correlation coefficient, r, was calculated using Microsoft ${ }^{\circledR}$ Excel 97. The statistical test for significance is based on critical values of r (Zar 1999).

\section{RESULTS}

Surface salinity fluctuated cyclically between $>30$ in January and 5 in July at NM6, and the fluctuation was almost in synchrony with that at SM17 (Fig. 2). Surface salinity usually remained $>10$ in July at SM17. At the station farthest away from the influence of the Pearl River, the seasonal fluctuation in surface salinity was much smaller with salinity $>25$ all the time. At MM11, the fluctuation in salinity was intermediate between MM4 and SM19 (Fig. 2). Salinity in the bottom deep water remained high (>30) and showed an increase when the surface salinity decreased at the same time in summer at all the stations except for NM6, where salinity at surface and bottom decreased at the same time. The decrease in salinity during the wet season (March to September) most likely increased stratification of the water column at NM6, SM17 and SM19, while stratification occurred during a shorter period at MM11 and an even shorter period at MM4. The degree of stratification (based on salinity differences between surface and bottom) was small at MM4 and MM11 compared to the other 3 stations. Temperature at the surface showed an apparent cyclic fluctuation between 


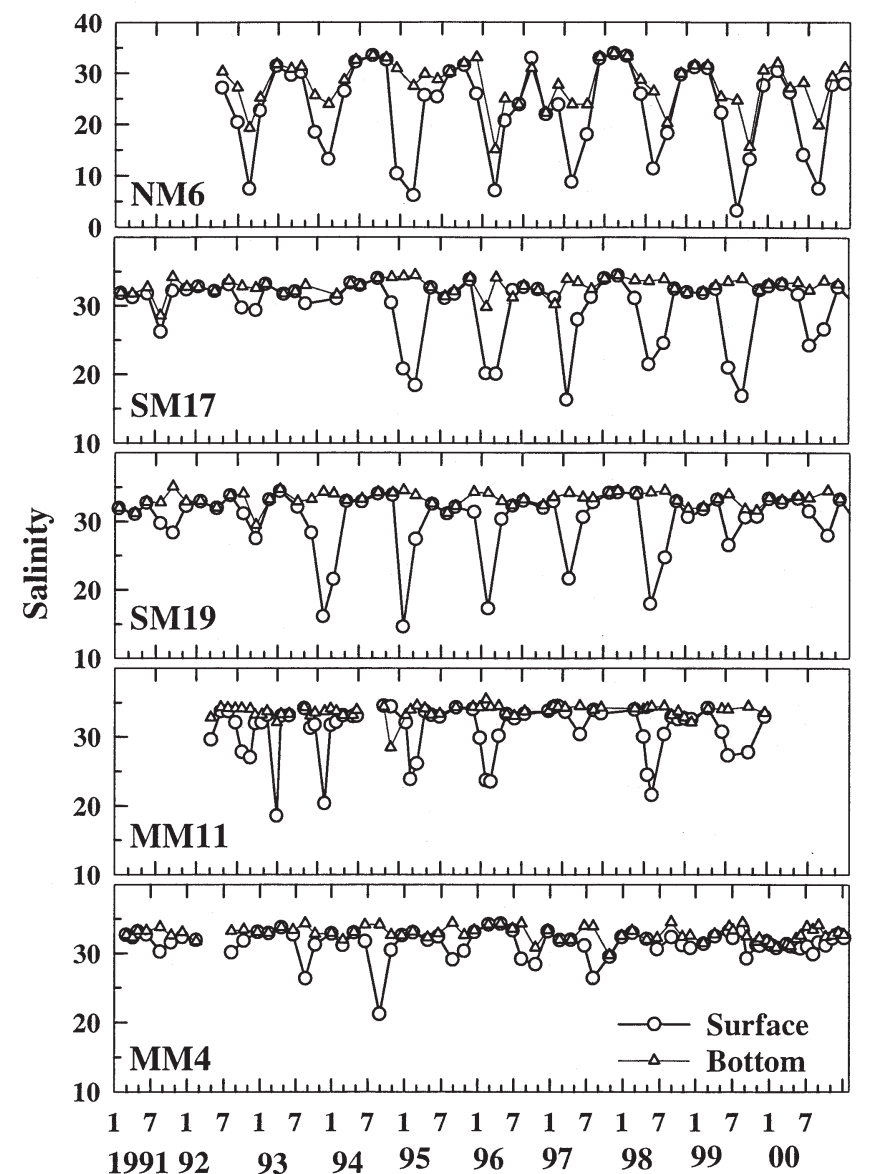

Fig. 2. Time series of salinity at the surface and bottom at 5 stations from 1991 to 2000 . Numbers 1 and 7 on the $x$-axis represent January and July, respectively

about 28 and $30^{\circ} \mathrm{C}$ in summer, and 15 and $17^{\circ} \mathrm{C}$ in winter at all stations (Fig. 3). When the surface temperature increased, the bottom temperature decreased during summer. The thermal stratification appeared to start and end earlier than the haline stratification (Fig. 3).

There appeared to be a temporal progression of chl a maximum around Hong Kong. Chl a concentration at NM6 was low during March, and increased during April and May. Chl a concentration remained at $<3 \mu \mathrm{g} \mathrm{l}^{-1}$ from June to November and increased during December and January (Fig. 4). The highest monthly chl a concentration at NM6 was $<10 \mu \mathrm{g} \mathrm{l}^{-1}$. At SM17, chl a concentration increased during May and June (ca. $10 \mu \mathrm{g} \mathrm{l}^{-1}$ ), 1 mo later than at NM6, and remained at

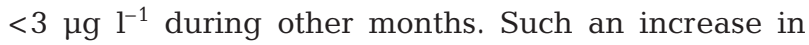
chl a concentrations occurred during June and July at SM19. The maximum chl a during July reached $>15 \mathrm{\mu g} \mathrm{l}^{-1}$ (Fig. 4). Chl a concentration at MM11 was bell-shaped with the maximum around July (Fig. 4). Chl a concentration at MM4 remained low $<3 \mu \mathrm{g} \mathrm{l}^{-1}$ and did not appear to be part of the fluctuations at other stations (Fig. 4). In many instances, the chl a concentrations at the bottom increased at the same time as $\mathrm{chl} a$ at the surface. For example, chl $a$ in July at SM19 increased in the bottom water. Chl a was even higher at the bottom than at the surface during June at MM4 (Fig. 4).

There was a seasonal change in the surface $\mathrm{NO}_{3}$ concentration at NM6 with peaks in summer and lows in winter (Fig. 5). Monthly peak $\mathrm{NO}_{3}$ concentrations were around $80 \mu \mathrm{M}$ during June (Fig. 5), reaching $100 \mu \mathrm{M}$ in 1993 and 1996 at NM6 (data not shown). Low $\mathrm{NO}_{3}$ concentrations were $<5 \mu \mathrm{M}$. The seasonal changes in $\mathrm{NO}_{3}$ occurred at SM17, SM19 and MM11, but the increase in spring was 1 mo behind those at NM6, and the return to the winter low concentration was 1 mo earlier than at NM6 (Fig. 5). The peak concentrations at MM11 were lower than SM17 and 19. $\mathrm{NO}_{3}$ concentrations at the surface and bottom at MM4 were very low, $<2.5 \mu \mathrm{M}$ all year round, except for August at the bottom (Fig. 5). The seasonal change in $\mathrm{SiO}_{4}$ was very similar to $\mathrm{NO}_{3}$ at NM6, SM17 and

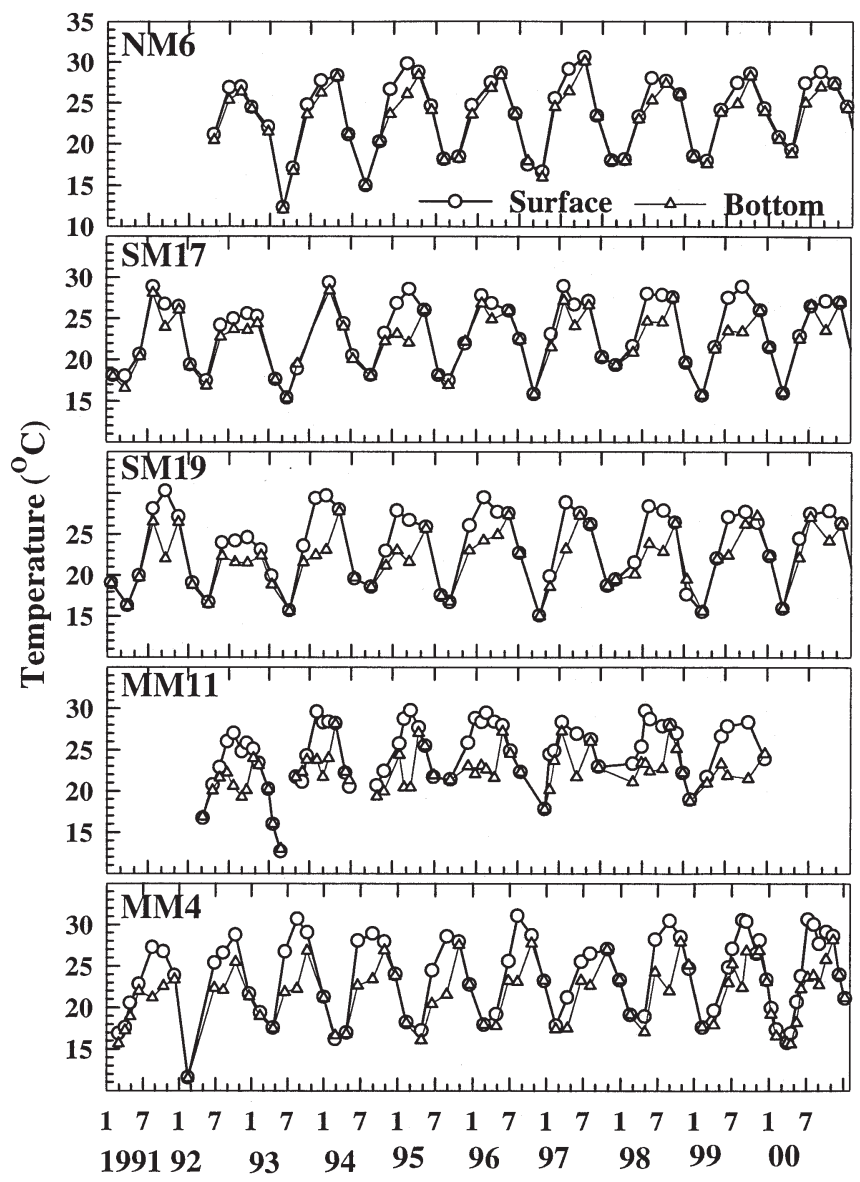

Fig. 3. Time series of temperature at the surface and bottom at 5 stations from 1991 to 2000 . Numbers 1 and 7 on the $x$-axis represent January and July, respectively 
SM19, and $\mathrm{SiO}_{4}$ concentrations were generally higher than $\mathrm{NO}_{3}$ at the surface at all stations (Fig. 6). At MM11 and MM4, the temporal variation in $\mathrm{SiO}_{4}$ appeared to be less regular between these 2 stations compared with other stations and there were no covariations between these 2 stations (Fig. 6). At MM4, $\mathrm{SiO}_{4}$ concentrations at surface were low from April to June $(<4 \mu \mathrm{M})$ and increased afterwards. The highest $\mathrm{SiO}_{4}$ concentration occurred during December (Fig. 6). $\mathrm{PO}_{4}$ concentrations were generally $<1 \mu \mathrm{M}$ at all stations except for NM6 (Fig. 7). At SM19, MM11 and $\mathrm{MM} 4, \mathrm{PO}_{4}$ concentrations were $<0.5 \mu \mathrm{M}$ during most months. In constrast to $\mathrm{NO}_{3}$ and $\mathrm{SiO}_{4}, \mathrm{PO}_{4}$ showed no particular pattern of seasonal variations. $\mathrm{PO}_{4}$ at the bottom was slightly higher than at the surface on average (Fig. 7).

There were seasonal variations in the N:P ratio (Fig. 8). At NM6, the N:P ratio at the surface was near 24:1 from January to March and increased to $>40: 1$ between spring and summer. N:P ratios at the surface were between 16 and 32:1 from February to May and

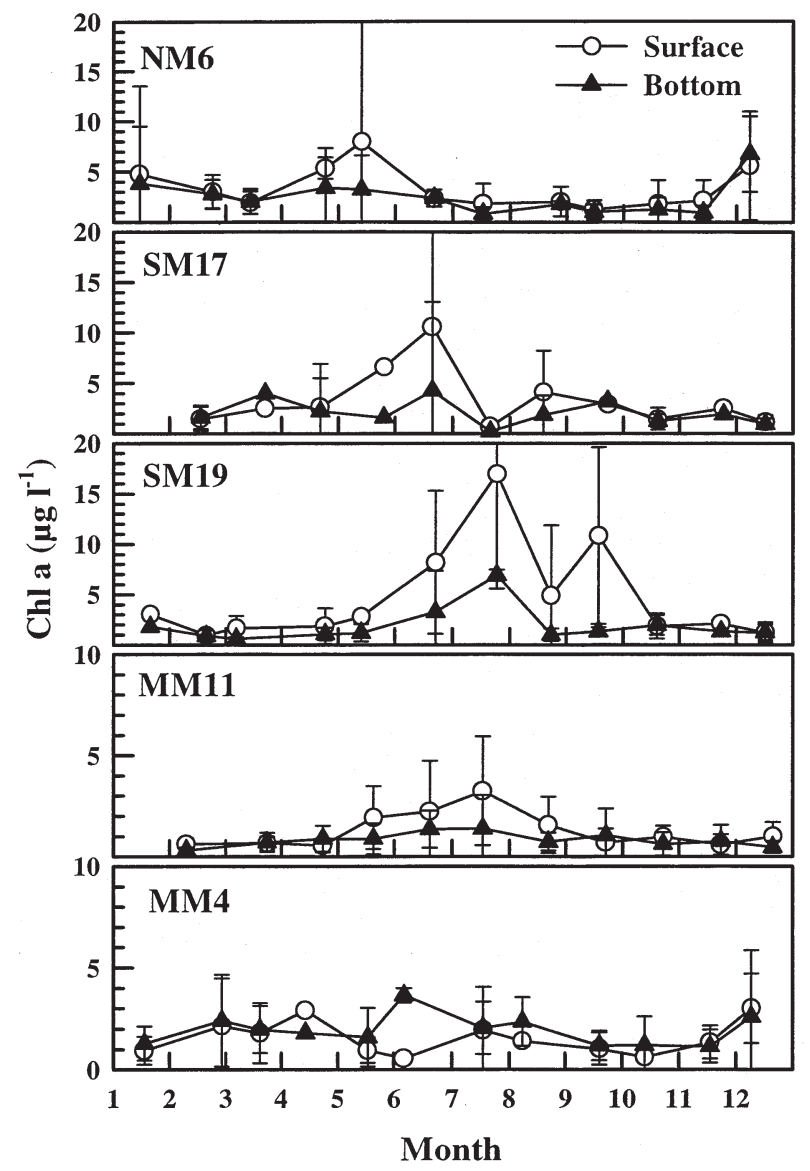

Fig. 4. Monthly average chl $a$ at the surface and bottom at 5 stations from 1991 to 2000. Note the different scales for MM4 and MM11. Vertical bars indicate SD. Numbers 1 to 12 on the $x$-axis represent January to December, respectively exceeded 80:1 at SM17, SM19 and MM11 during June. The high N:P ratio persisted during July at SM19. However, at MM4, N:P ratios were <16:1 all the time except in July. N:Si ratios were usually lower or close to $1: 1$, but exceeded $1: 1$ in January to February and April to May at NM6, and during June at SM17 and SM19. N:Si ratios were particularly high (4:1) in July at MM11. N:Si ratios remained <0.5:1 from August to December, but increased to close to 1:1 from April to July at MM4 (Fig. 9).

Most of the fluctuations in temperature, chl $a, \mathrm{NO}_{3}$ and $\mathrm{SiO}_{4}$ as well as N:P were significantly negatively related with variations in salinity (Table 1). For example, at NM6, concentrations of 2 nutrients $\left(\mathrm{NO}_{3}\right.$ and $\mathrm{SiO}_{4}$ ) decreased linearly with salinity (Fig. 10), with 81 and $93 \%$ of the variations in $\mathrm{NO}_{3}$ and $\mathrm{SiO}_{4}$, respectively, being accounted for by the variation in salinity, and 88 to 94 and 78 to $82 \%$ being accounted for at SM17 and SM19, respectively. The intercept at salinity $=0$ of each regressed line for a station represented the source concentrations of $\mathrm{NO}_{3}$ and $\mathrm{SiO}_{4}$. The con-

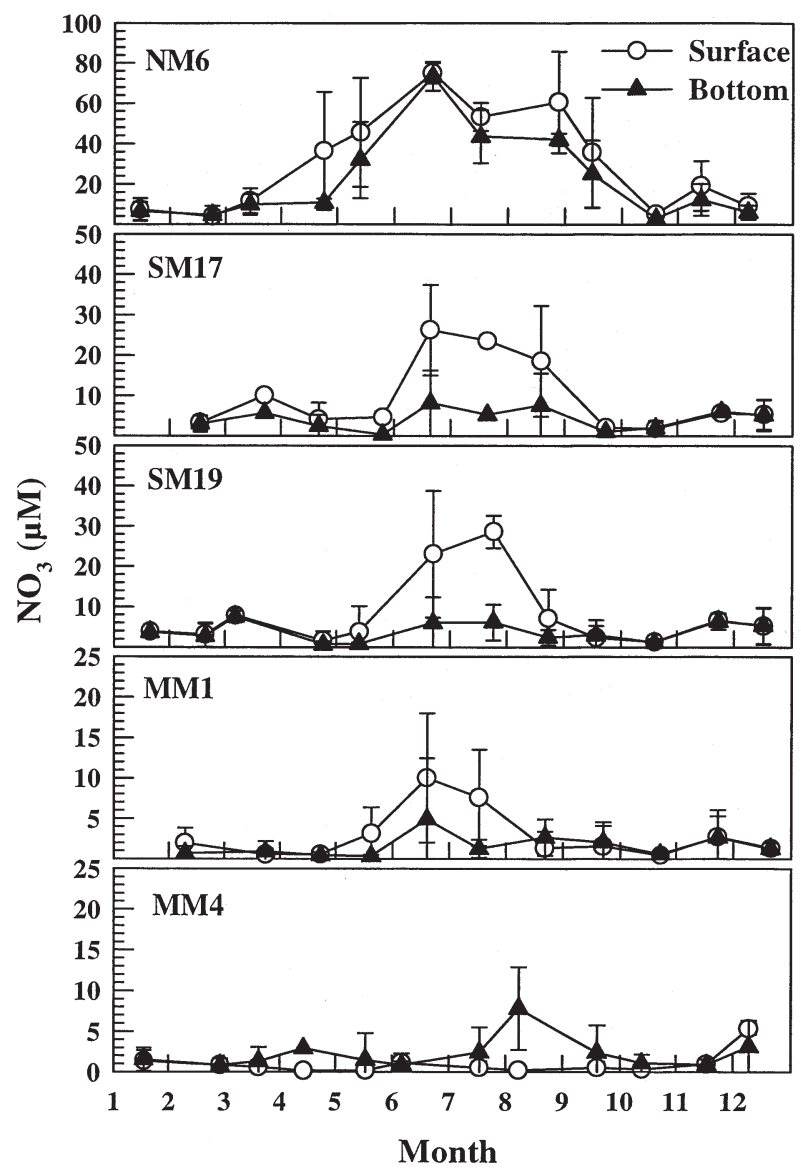

Fig. 5. Monthly average $\mathrm{NO}_{3}$ at the surface and bottom at 5 stations from 1991 to 2000 . Note the different scales among the 5 stations. Vertical bars indicate SD. Numbers 1 to 12 on the $x$-axis represent January to December, respectively 


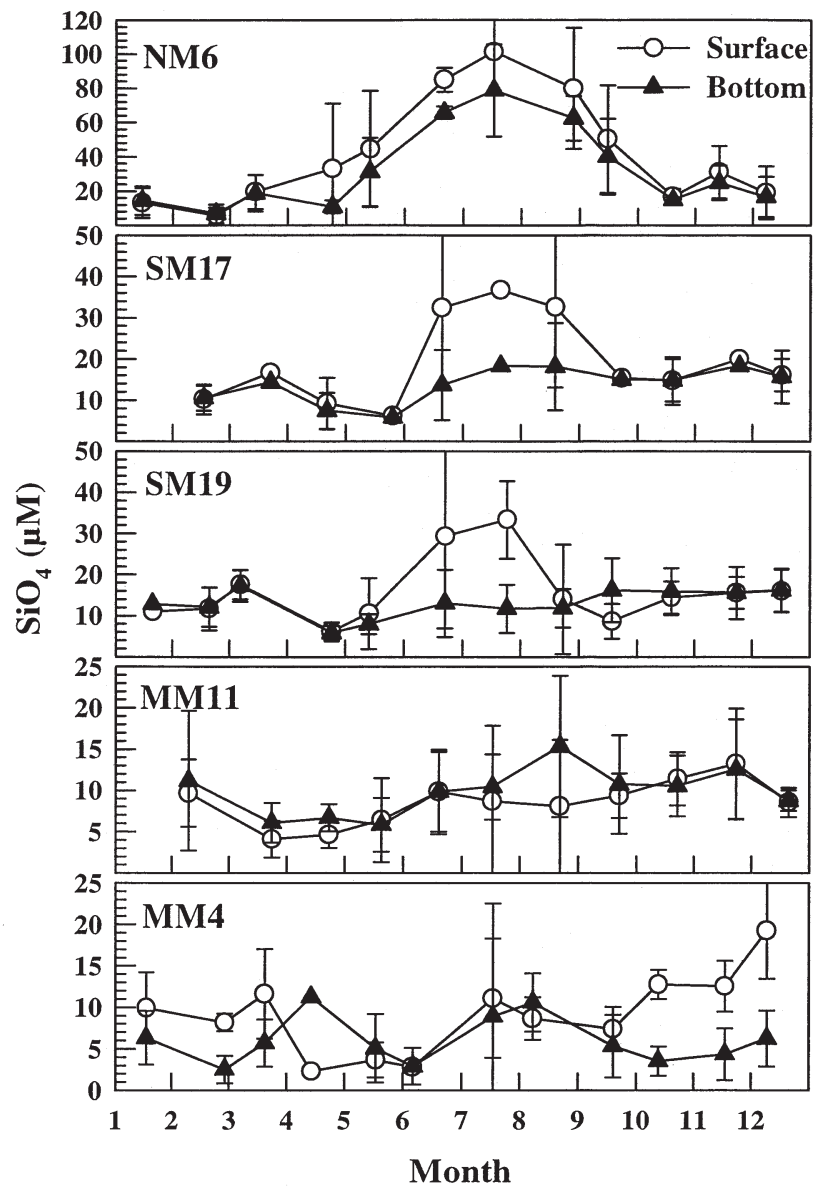

Fig. 6. Monthly average $\mathrm{SiO}_{4}$ at the surface and bottom at 5 stations from 1991 to 2000 . Vertical bars indicate SD. Numbers 1 to 12 on the $x$-axis represent January to December, respectively

centrations of $\mathrm{NO}_{3}$ and $\mathrm{SiO}_{4}$ at the intercepts were 90 and $138 \mu \mathrm{M}$, respectively, at NM6; 72 to 57 and 91 to $79 \mu \mathrm{M}$, respectively, at SM17 and SM19; and 29 and $26 \mu \mathrm{M}$, respectively, at MM11. Co-variation between salinity and other variables were weak at MM11, although the correlations were statistically significant (Table 1). However, at MM4, there were no significant correlations between salinity and other variables except for temperature (Table 1).

Monthly average surface chl a over $10 \mathrm{yr}$ was correlated significantly negatively with salinity at all the stations except for NM6, but the correlation was significantly positive for the bottom of NM6 (Fig. 11, Table 2). Monthly average surface chl a was significantly correlated with $\mathrm{NO}_{3}+\mathrm{NH}_{4}$ and $\mathrm{SiO}_{4}$, and the significant correlation between chl $a$ and $\mathrm{NO}_{3}+\mathrm{NH}_{4}$ was positive at SM17, SM19 and MM11 as well as MM4, but only significant at SM17 and SM19 for $\mathrm{SiO}_{4}$ (Fig. 11, Table 2).

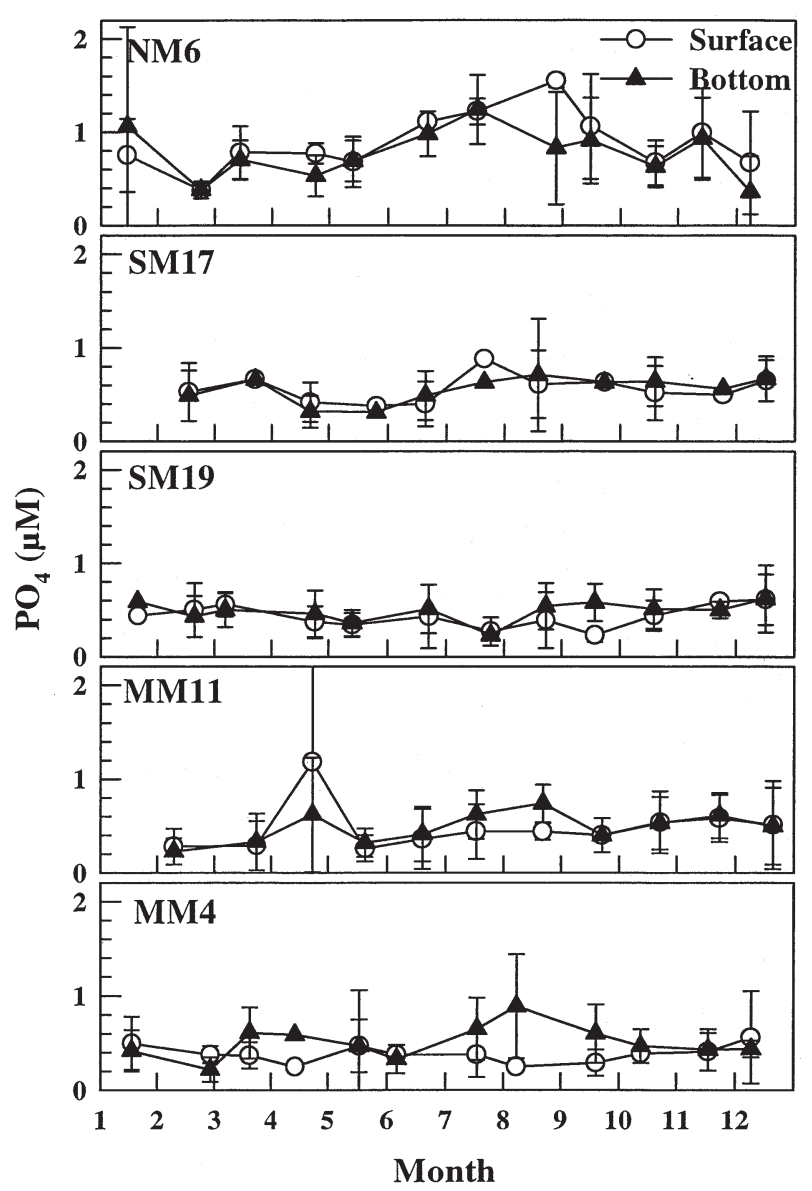

Fig. 7. Monthly average $\mathrm{PO}_{4}$ at the surface and bottom at 5 stations from 1991 to 2000 . Vertical bars indicate SD. Numbers 1 to 12 on the $x$-axis represent January to December, respectively

\section{DISCUSSION}

\section{Monsoons, river outflow and water mass and circulation}

The strong seasonal changes in salinity, temperature, chl a and nutrients appeared to be closely coupled with seasonal monsoons and the Pearl River

Table 1. Correlation coefficient, $r$, between surface salinity and other parameters at 5 stations from 1991 to 2000. The degrees of freedom, are equal to the sampling times $n$, minus $1(n-1)$. Bold values indicate $p<$ 0.05 and are considered to be statistically significant based on the critical values for $r$ by Zar (1999)

\begin{tabular}{|lrrrrrrrrr|}
\hline & $\mathrm{n}$ & $\mathrm{Temp}$. & $\mathrm{Chl} a$ & $\mathrm{NO}_{3}$ & $\mathrm{SiO}_{4}$ & $\mathrm{PO}_{4}$ & $\mathrm{NH}_{4}$ & $\mathrm{~N}: \mathrm{P}$ & $\mathrm{N}: \mathrm{Si}$ \\
\hline NM6 & 41 & $\mathbf{- 0 . 7 2}$ & 0.03 & $\mathbf{- 0 . 8 1}$ & $\mathbf{- 0 . 9 3}$ & $\mathbf{- 0 . 4 1}$ & 0.25 & -0.22 & 0.21 \\
SM17 & 46 & $\mathbf{- 0 . 6 0}$ & $\mathbf{- 0 . 6 6}$ & $\mathbf{- 0 . 9 4}$ & $\mathbf{- 0 . 8 2}$ & -0.10 & -0.04 & $\mathbf{- 0 . 5 4}$ & -0.12 \\
SM19 & 47 & $\mathbf{- 0 . 5 6}$ & $\mathbf{- 0 . 4 0}$ & $\mathbf{- 0 . 8 8}$ & $\mathbf{- 0 . 7 8}$ & -0.15 & -0.05 & $\mathbf{- 0 . 5 8}$ & -0.13 \\
MM11 & 59 & $\mathbf{- 0 . 4 1}$ & $\mathbf{- 0 . 4 4}$ & $\mathbf{- 0 . 7 1}$ & $\mathbf{- 0 . 3 7}$ & 0.09 & -0.24 & $\mathbf{- 0 . 3 9}$ & $\mathbf{- 0 . 4 6}$ \\
MM4 & 42 & $\mathbf{- 0 . 5 7}$ & -0.15 & -0.04 & -0.21 & 0.01 & -0.07 & 0.07 & 0.03 \\
\hline
\end{tabular}




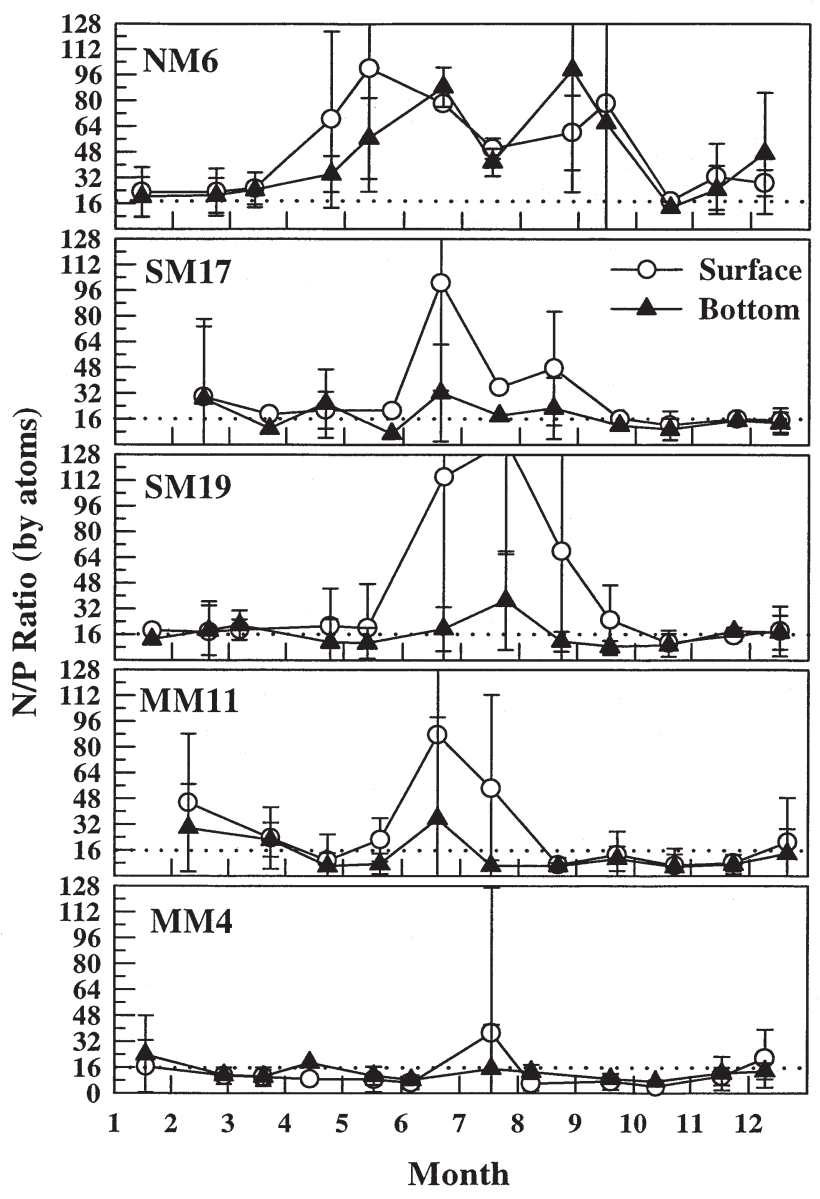

Fig. 8. Monthly average N:P ratios at the surface and bottom at 5 stations from 1991 to 2000 . Vertical bars indicate SD. Numbers 1 to 12 on the $x$-axis represent January to December, respectively

discharge. Hong Kong experiences the NE monsoon in winter and the S-SW monsoon in summer (Fig. 12). Wind speeds are stronger $\left(7.5\right.$ to $\left.8 \mathrm{~m} \mathrm{~s}^{-1}\right)$ in the NE direction than in the S-SW $\left(<6.5 \mathrm{~m} \mathrm{~s}^{-1}\right)$ (Fig. 12). The Pearl River discharge is low $\left(3343 \mathrm{~m}^{3} \mathrm{~s}^{-1}\right)$ in winter and reaches a maximum $\left(22189 \mathrm{~m}^{3} \mathrm{~s}^{-1}\right)$ in July (Zhao 1990). In winter, the Pearl River estuary and coastal waters of Hong Kong are dominated by the China Coastal Current from the NE (Watts 1973, Yin et al. 1999). Salinity was high at the surface and the water column was mixed homogeneously during this period (Figs. $2 \& 3$ ). In summer, the Pearl River estuary was dominated by a typical salt wedge structure and the estuarine circulation-outflow of the estuarine plume at the surface layer and inflow of salt water at the bottom layer (Yin et al. 2001). The estuarine plume flows out of the estuary, forming the coastal plume and spreads to the southern waters of Hong Kong, as indicated by the decreased salinity at SM17 and SM19. The coastal plume was evident at MM11, indicating the movement across the southern waters of Hong Kong, but became much less evident at MM4. Both coastal upwelling due to the Coriolis effect resulting from the SW monsoon along the shore and the outflow of the Pearl River drive the offshore movement of the coastal plume (Watts 1973). As a result, the deep oceanic seawater on the continental shelf from the South China Sea moves towards the shore at the bottom to compensate for the surface outflow (Chau \& Wong 1960). This deep oceanic movement was clearly seen as an increase in salinity and a decrease in temperature at the bottom in summer at all the stations except for NM6 (Figs. 2 \& 3). The salinity reached $>33$ and the temperature dropped to $22^{\circ} \mathrm{C}$ at the bottom at SM17, and these values were similar to the deep shelf water from the South China Sea (Chau \& Wong 1960).

\section{Eutrophication}

Concentrations of nutrients respond to the dominance of different water masses during seasonal

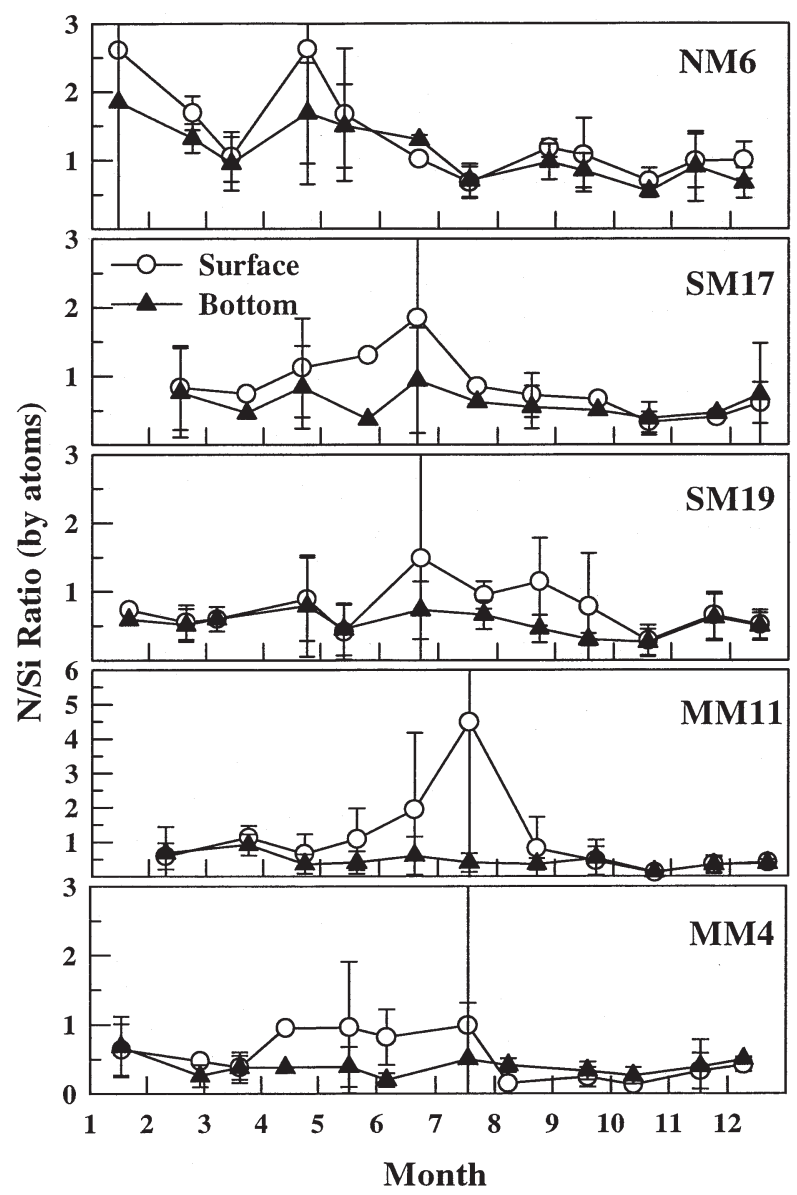

Fig. 9. Monthly average N:Si ratios at the surface and bottom at 5 stations from 1991 to 2000. Vertical bars indicate SD. Numbers 1 to 12 on the $x$-axis represent January to December, respectively 
Table 2. Correlation coefficient, $r$, between chl $a$ and other parameters at 5 stations using averaged data for each month over 10 yr from 1991 to 2000 (e.g. averaging data in January over $10 \mathrm{yr}$ to obtain an average for January). example, for bi-monthly sampling, $\mathrm{n}=6$. Bold values indicate $\mathrm{p}<0.05$ and are considered to be statistically significant based on the critical values for r by Zar (1999)

\begin{tabular}{|lrrrcrcrc|}
\hline & $\mathrm{n}$ & Salinity & $\mathrm{T}$ Temp. & $\mathrm{NO}_{3}+\mathrm{NH}_{4}$ & $\mathrm{SiO}_{4}$ & $\mathrm{PO}_{4}$ & $\mathrm{~N}: \mathrm{P}$ & $\mathrm{N}: \mathrm{Si}$ \\
\hline NM6 & 5 & 0.07 & 0.04 & 0.02 & -0.23 & -0.61 & 0.14 & $\mathbf{0 . 8 1}$ \\
SM17 & 5 & $\mathbf{- 0 . 9 4}$ & 0.64 & $\mathbf{0 . 9 2}$ & $\mathbf{0 . 8 3}$ & -0.53 & $\mathbf{0 . 9 4}$ & $\mathbf{0 . 8 3}$ \\
SM19 & 5 & $\mathbf{- 0 . 9 2}$ & 0.63 & $\mathbf{0 . 9 7}$ & $\mathbf{0 . 9 0}$ & -0.18 & $\mathbf{0 . 9 7}$ & $\mathbf{0 . 8 4}$ \\
MM11 & 10 & $\mathbf{- 0 . 9 0}$ & 0.64 & $\mathbf{0 . 8 0}$ & 0.01 & -0.29 & 0.61 & $\mathbf{0 . 8 8}$ \\
MM4 & 5 & $\mathbf{- 0 . 7 6}$ & 0.35 & $\mathbf{0 . 8 7}$ & 0.65 & -0.30 & $\mathbf{0 . 9 4}$ & 0.49 \\
\hline
\end{tabular}
The degrees of freedom, $n$, are equal to the sampling times for a year. For

ents must be due to the estuarine influence and eutrophication. Comparing the $\mathrm{NO}_{3}$ concentration at SM19 to that near Waglan Island (near SM19) during 1973 (Morton \& Wu 1975), indicates that $\mathrm{NO}_{3}$ at SM19 has increased at least 3 times during this $30 \mathrm{yr}$ period. However, the concentration of phosphorus does not have appeared to have increased since then, remaining below $1 \mu \mathrm{M}$. Even a large-scale investigation in the region in 1980 to 1981 (Yin et al. unpubl. data) showed similar concentrations of phosphorus to this study.

shifts. The South China Sea is an oligotrophic ocean and thus, coastal waters of Hong Kong in winter and deep waters in summer are nutrient-poor. Therefore, any long-term increases in concentrations of nutri-

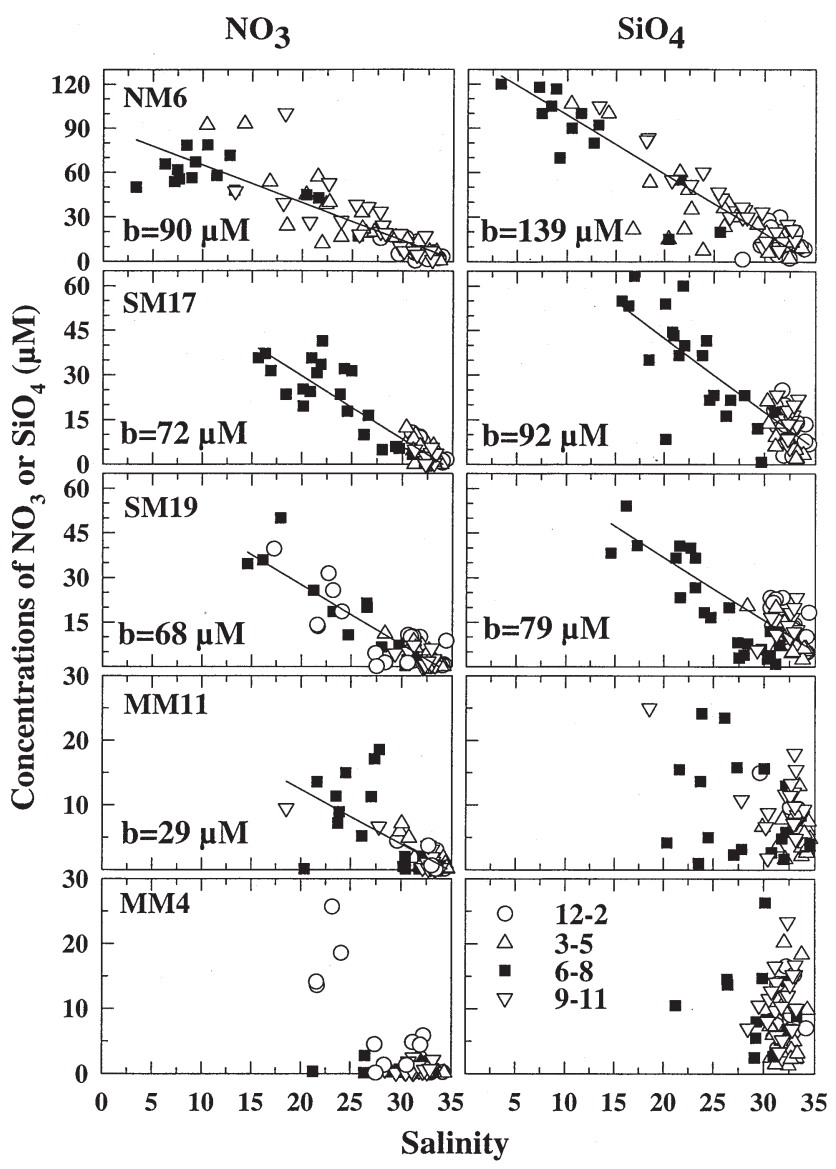

Fig. 10. Concentrations of $\mathrm{NO}_{3}$ and $\mathrm{SiO}_{4}$ versus salinity at 5 stations for the surface data from the time series from 1991 to 2000 . The graphs with lines indicate significant correlation between the 2 variables and the correlation coefficients are given in Table 1. The intercept of the regression line is represented by $\mathrm{b}$. The 4 different symbols represent the 4 seasons: 12-2 = December to February, 3-5 = March to May; 6-8 = June to August; and 9-11 = September to November
The significant correlations between salinity and $\mathrm{NO}_{3}$ or $\mathrm{SiO}_{4}$ suggest that concentrations of $\mathrm{NO}_{3}$ and $\mathrm{SiO}_{4}$ from the freshwater source have not changed in the last 10 yr (Table 1, Fig. 10). If the concentration of $\mathrm{NO}_{3}$ and $\mathrm{SiO}_{4}$ from the freshwater as a source had increased significantly over the years, the concentration in the freshwater-seawater mixture at the same
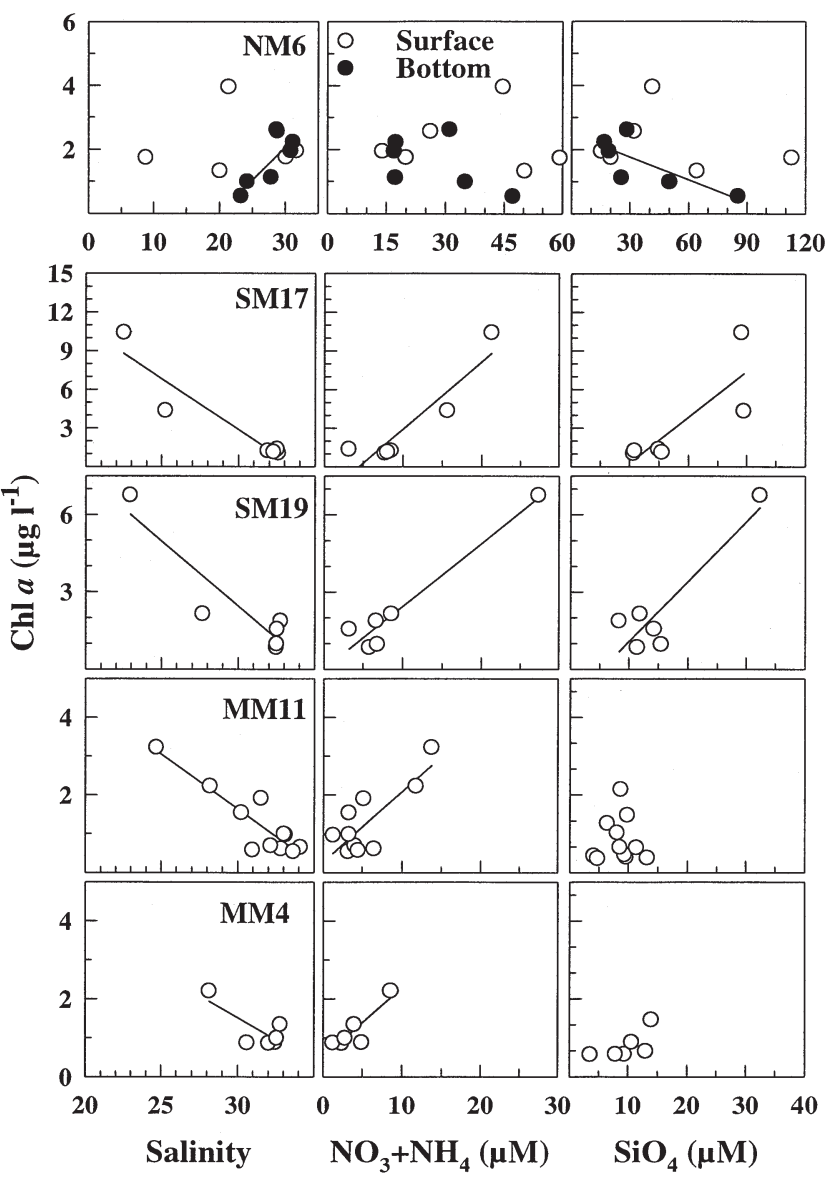

Fig. 11. Monthly average chl a versus monthly average salinity, monthly average of $\mathrm{NO}_{3}+\mathrm{NH}_{4}$ and monthly average $\mathrm{SiO}_{4}$ for the surface at all stations, except for at NM6, where bottom and surface averages are given 


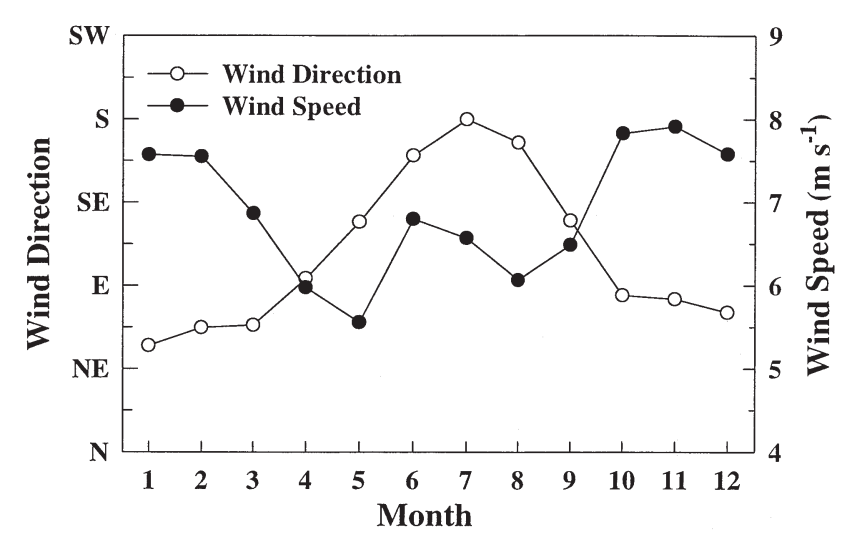

Fig. 12. Average daily wind direction and speed for each month over $10 \mathrm{yr}$ from 1991 to 2000. Numbers 1 to 12 on the $x$-axis represent January to December, respectively

salinity should have increased, which would result in a deviation from the conservative mixing line. Particularly, at NM6, the intercept concentration of $\mathrm{N}$ is about $90 \mu \mathrm{M}$, which is similar to that upstream in the Pearl River estuary (Yin et al. 2000, 2001). The lower extrapolated intercept concentrations at SM17 and SM19 of $\mathrm{NO}_{3}$ (Fig. 10) suggested biological utilization of $\mathrm{N}$ during the eastward movement of the coastal plume from the estuary.

$\mathrm{P}$ limitation may play an important role in controlling eutrophication in the region. $\mathrm{N}$ concentrations in the Pearl River were comparable to those of the Mississippi River (60 to $120 \mu \mathrm{M}$; Dortch \& Whitledge 1992, Rabalais et al. 1996) and to Chesapeake Bay, where $\mathrm{NO}_{3}$ in the freshwater region ranged between 70 and $120 \mu \mathrm{M}$ (Ward \& Twilley 1986, Fisher et al. 1988). However, severe large-scale eutrophication effects like the 'dead water zone' in the Gulf of Mexico due to the high nutrient loading from the Mississippi River (Rabalais et al. 1994, Malakoff 1998) have not been reported for the Pearl River estuary. In contrast to the Mississippi River and Gulf of Mexico, where the phosphorus concentration is high ( 3 to $5 \mu \mathrm{M}$; Dortch et al. 1992), phosphorus is low in the Pearl River estuary and the coastal plume (Yin et al. 2000, 2001). The phosphorus concentration in South China Sea is also low $(<0.5 \mu \mathrm{M}$; SCSIO 1985). Dissolved $\mathrm{PO}_{4}$ in 1980 in the Pearl River estuary (SCSIO 1985) was generally $<1 \mu \mathrm{M}$ in summer, which is similar to present concentrations, suggesting $\mathrm{PO}_{4}$ enrichment has not occurred in the Pearl River estuary during the last 2 decades. Therefore, low P could be a factor limiting a further increase in eutrophication in the Pearl River estuarine and coastal ecosystem. The fact that chl a values at 5 stations from 1991 to 2000 are relatively low when considering very high $\mathrm{N}$ concentrations, supports this notion.

There is a spatial and temporal progression in annual peaks of chl a around Hong Kong in the Pearl
River estuary (NM6) during April and May, to the southern waters on the west side (SM17) during May and June, and farther east (SM19) during June and July. The coastal waters south of Hong Kong are a region where chl $a$ is often maximum since these waters are frequently at the edge of the coastal plume during the season of high discharge by the Pearl River (Yin et al. 2000, unpubl. data). The peaks were rela-

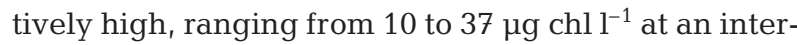
mediate salinity in the southern waters of Hong Kong (data not shown in Fig. 4; Yin et al. 2000, unpubl. data). The highest chl a concentration is similar to values found at the plume/oceanic interface of the Mississippi River (Lohrenz et al. 1999). Although nutrients were high throughout the estuary at all times of the year, chl a concentrations were low $\left(<5 \mu \mathrm{g} \mathrm{l^{-1 }}\right)$ at NM6 with only brief excursions above $10 \mu \mathrm{g} \mathrm{l}^{-1}$. This suggests that phytoplankton biomass and productivity are controlled by rapid dilution by river outflow and light limitation (Yin et al. unpubl. data) due to high turbidity at NM6 (Fig. 13), where the average Secchi disk read-

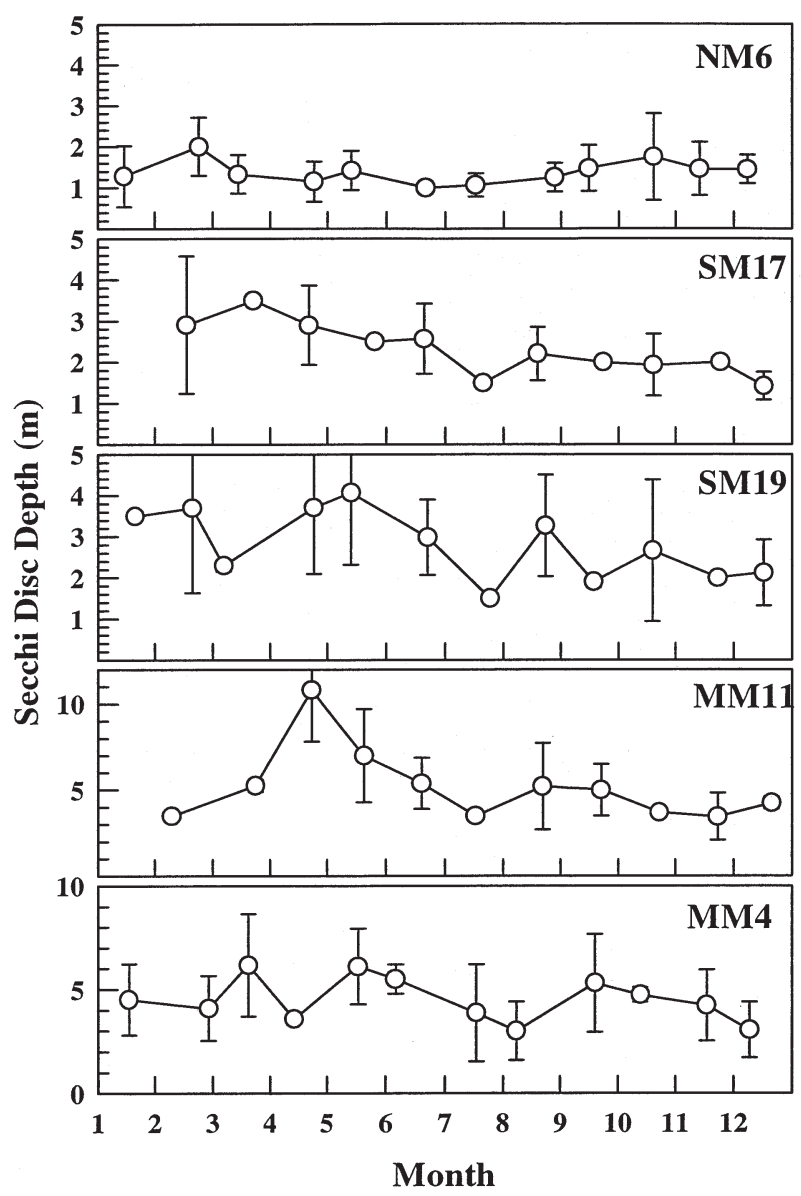

Fig. 13. Monthly average Secchi Disc depths at 5 stations from 1991 to 2000 . Numbers 1 to 12 on the $x$-axis represent January to December, respectively 
ing was only around $1 \mathrm{~m}$ deep (Fig. 13). High phytoplankton biomass develops downstream, often at the edge of the coastal plume. This has been observed in other estuaries such as Chesapeake Bay (Breitburg 1990, Harding 1994), New York Bight (Malone 1977) and the Strait of Georgia (Yin et al. 1997). Therefore, it is reasonable to see a significant negative correlation between chl $a$ and salinity, but it is interesting to note a positive correlation between chl a and $\mathrm{NO}_{3}+\mathrm{NH}_{4}$ or $\mathrm{SiO}_{4}$ (Fig. 11). Normally, chl a should be inversely related to nutrients when they are in the same water system. A positive relation at a station can only indicate a change of water masses during different sampling times. This suggests that $\mathrm{chl} a$ in the southern waters of Hong Kong varies with the degree of the coastal plume influence that changes with seasons. Part of the algal biomass sinks to the deeper waters, and decomposition of algae results in low oxygen (Malone et al. 1988, Smetacek et al. 1991). High chl a near the bottom in summer did reflect an accumulation of sinking phytoplankton at SM17 (Fig. 4). The settled phytoplankton below the coastal plume can be carried back into the estuary, as shown by a positive correlation of chl a with salinity, but a negative correlation with $\mathrm{SiO}_{4}$ and $\mathrm{NO}_{3}+\mathrm{NH}_{4}$ for the bottom water at NM6; although the relation was not significant for $\mathrm{NO}_{3}+\mathrm{NH}_{4}$ (Table 2). As a result of sinking phytoplankton, dissolved oxygen in summer periodically decreased at the bottom of SM17 and SM19 (EPD 1999).

\section{Significance of nutrient limitation}

Nutrient enrichment processes have major significance for coastal management. At present, the Hong Kong government is reviewing its sewage treatment strategy. The removal of $\mathrm{N}$ has been considered (IRP 2000), but not removal of phosphorus. However, if phosphorus is the most limiting nutrient of phytoplankton biomass production, the most cost-effective strategy would be to control phosphorus discharge in the sewage effluent. High N:P ratios in summer are due to the influence of the estuarine coastal plume (SM17 and SM19, and even MM11) and are consistent with the previous observation in which the N:P ratio in freshwater from the Pearl River was $>100: 1$, suggesting $P$ limitation in the Pearl River estuary (Zhang et al. 1999, Yin et al. 2000, 2001). In the eastern waters (MM4) of Hong Kong, beyond the western edge of the Pearl River coastal plume, low N:P ratios <10:1 supported the suggestion that there is a shift from $\mathrm{P}$ to $\mathrm{N}$ limitation in summer from west to east in the Hong Kong coastal waters, as observed during July 1999 using nutrient addition experiments (Yin et al. 2001). Similarly, when N:P ratios change from low N:P ratio
$<16: 1$ in winter to $>16: 1$ during summer, there is very likely a seasonal shift from potential $\mathrm{N}$ to $\mathrm{P}$ limitation during spring in the southern waters of Hong Kong. In addition, when concentrations of N, P and Si are all low in winter, sewage effluent may not impose a eutrophication impact to the coastal waters of Hong Kong. Nevertheless, these seasonal and spatial nutrient conditions thus compound the most limiting nutrient issue in determining the precise sewage treatment level and which nutrient, $\mathrm{N}$ or $\mathrm{P}$, should be removed by the biological treatment of the sewage. Comprehensive studies are needed in order to understand the spatial and temporal nutrient limitations around Hong Kong, as well as to formulate the long-term strategic plan for sewage treatment.

In summary, monsoons and the Pearl River discharge play a dominant role in the spatial and temporal distribution of nutrients and nutrient ratios in the Pearl River estuary and adjacent waters. The South China Sea is an oligotrophic ocean, and therefore the exchange between the oceanic waters and the coastal waters of Hong Kong is important to reduce the eutrophication effects seasonally and yearly. Monsoons and river outflow serve as important physical driving forces to flush the coastal waters of Hong Kong. During the summer season, the upwelling resulting from the SW monsoon and the offshore movement of the estuarine plume due to the outflow of the Pearl River and deep shoreward movement of the oceanic waters from the South China Sea can be a very important mechanism for flushing coastal waters, and hence, lessening the seasonal accumulative effects of nutrient enrichment in the Hong Kong waters. During the winter season, the waters brought by the NE monsoon, flush the entire coastal waters of Hong Kong; this would serve as an important mechanism to reduce the long-term accumulative eutrophication impact of organic matter in the bottom waters and sediments during the following spring and summer. Otherwise, the coastal waters of Hong Kong might have become more heavily eutrophied than they are at present, considering the daily discharge of over 2.2 million $t$ of domestic sewage in Hong Kong (Sin et al. 1995) and the high N concentrations from the Pearl River (Yin et al. 2001). Low phosphorus concentrations play an important role in controlling phytoplankton biomass production during spring and summer, and therefore reduce the eutrophication effect due to $\mathrm{N}$ enrichment, which would otherwise most likely result in much higher phytoplankton biomass.

Acknowledgements. We thank the Environmental Protection Department, Hong Kong Government, for providing the data on the water quality in the marine waters of Hong Kong and for permission to publish them. 


\section{LITERATURE CITED}

APHA (American Public Health Association) (1995) Standard methods for the examination of water and wastewater: including bottom sediments and sludges. American Public Health Association, New York

ASTM (American Society for Testing and Materials) (1991) Annual book of ASTM standards. ASTM, Philadelphia

Breitburg DL (1990) Near-shore hypoxia in the Chesapeake Bay: patterns and relationships among physical factors. Estuar Coast Shelf Sci 30:593-609

Bricker SB, Clement CG, Pirhalla DE, Orlando SP, Farrow DGG (1999) National estuarine eutrophication assessment: effects of nutrient enrichment in the nation's estuaries. Special Projects Office and the National Centers for Coastal Ocean Science, National Ocean Service, National Oceanic and Atmospheric Administration, Silver Spring, $\mathrm{MD}$

Cadée GC, Hegeman J (1986) Seasonal and annual variation in Phaeocystis pouchetii (Haptophyceae) in the westernmost inlet of the Wadden Sea during the 1973 to 1985 period. Neth J Sea Res 20:29-36

Chau YK, Wong CS (1960) Oceanographic investigations in the northern region of the South China sea off Hong Kong. Hong Kong Univ Fish J 3:1-25

Cloern JE (1996) Phytoplankton bloom dynamics in coastal ecosystems: a review with some general lessons from sustained investigation of San Francisco Bay, California. Rev Geophys 34:127-168

Cloern JE (2001) Our evolving conceptual model of the coastal eutrophication problem. Mar Ecol Prog Ser 210: $223-253$

Cooper S, Brush G (1991) Long-term history of Chesapeake Bay anoxia. Science 254:992-996

Dortch Q, Whitledge TE (1992) Does nitrogen or silicon limit phytoplankton production in the Mississippi River plume and estuary regions? Cont Shelf Res 12:1293-1309

Dortch Q, Milsted D, Rabalais NN, Lohrenz SE, Redalje DG, Dagg MJ, Turner RE, Whitledge TE (1992) Role of silicate availability in phytoplankton species composition and the fate of carbon. In: Texas Sea Grant College Program (ed) Nutrient Enhanced Coastal Ocean Productivity, NECOP Workshop Proc, October 1991, NOAA Coastal Ocean Program, College Station, TX, p 76-83

Duce RA, Liss PS, Merrill JT, Atlas EL and 15 others (1991) The atmospheric input of trace species to the world's ocean. Global Biogeochem Cycles 5:193-259

EPD (Environmental Protection Department) (1999) Marine water quality in Hong Kong in 1998: results for 1998 from the Marine Monitoring Programme of the Environmental Protection Department. Hong Kong SAR Government, Hong Kong

Fisher TR, Harding LW Jr, Stanley DW, Ward LG (1988) Phytoplankton, nutrients and turbidity in the Chesapeake, Delaware and Hudson estuaries. Estuar Coast Shelf Sci 27: 61-93

Harding LW Jr (1994) Long-term trends in the distribution of phytoplankton in Chesapeake Bay: roles of light, nutrients and streamflow. Mar Ecol Prog Ser 104:267-291

Hills P, Zhang L, Liu J (1998) Transboundary pollution between Guangdong Province and Hong Kong: threats to water quality of the Pearl River Estuary and their implications for environmental policy planning. J Environ Plan Manage 41:375-396

Humborg C, Ittekot V, Cociosu A, Bodungen Bv (1997) Effect of Danube River dam on Black Sea biogeochemistry and ecosystem structure. Nature 386:385-388
IRP (International Review Panel) (2000) Review of Strategic Sewage Disposal Scheme. Hong Kong SAR Government, Hong Kong

Jickells TD (1998) Nutrient biogeochemistry of the coastal zone. Science 281:217-222

Lin GCS (1997) Red capitalism in south China: growth and development of the Pearl River Delta. UBC Press, Vancouver

Lohrenz SE, Fahnenstiel GL, Redalje DG, Lang GA, Dagg MJ, Whitledge TE, Dortch Q (1999) Nutrients, irradiance, and mixing as factors regulating primary production in coastal waters impacted by the Mississippi River plume. Cont Shelf Res 19:1113-1141

Malakoff D (1998) Death by suffocation in the Gulf of Mexico. Science 281:190-192

Malone TC (1977) Environmental regulation of phytoplankton productivity in the lower Hudson estuary. Estuar Coast Mar Sci 5:157-171

Malone TC, Crocker LH, Pike SE, Wendler BW (1988) Influences of river flow on the dynamics of phytoplankton production in a partially stratified estuary. Mar Ecol Prog Ser 48:235-249

Morton B, Wu SS (1975) The hydrology of the coastal waters of Hong Kong. Environ Res 10:319-347

Neller RJ, Lam KC (1994) The environment. In: Yeung YM, Chu DKY (eds) Guangdong: survey of a province undergoing rapid change. The Chinese University of Hong Kong Press, Hong Kong

Nixon SW, Ammerman JW, Atkinson LP, Berousky VM and 9 others (1996) The fate of nitrogen and phosphorus at the land-sea margin of the North Atlantic Ocean. Biogeochemistry 35:141-180

NRC (National Research Council) (2000) Clean coastal waters: understanding and reducing the effect of nutrient pollution. National Academy Press, Washington, DC

Parker CA, O'Reilly JE (1991) Oxygen depletion in Long Island Sound: a historical perspective. Estuaries 14:248-265

Rabalais NN, Turner RE, Justić D, Dortch Q, Wiseman WJ, SenGupta BK (1994) Nutrient changes in the Mississippi River and system responses on the adjacent continental shelf. Estuaries 19:386-407

Rabalais NN, Turner RE, Justić D, Dortch Q, Wiseman WJ Jr, Sen Gupta BK (1996) Nutrient changes in the Mississippi River system responses on the adjacent continental shelf. Estuaries 19:386-407

Riegman R, Noordeloos AAM, Cadée GC (1992) Phaeocystis blooms and eutrophication of the continental coastal zones of the North Sea. Mar Biol 112:479-484

Ruddle K, Zhong G (1988) Integrated agriculture-aquaculture in South China: the dike-pond system of the Zhujiang Delta. Cambridge University Press, Cambridge

SCSIO (South China Sea Institute of Oceanology) (1985) Report of multidisciplinary investigation of the South China Sea II. Academic Press, Beijing

Sin WS, Chan PK, Chau KM (1995) Sewage and stormwater disposal. In: Coastal infrastructure development in Hong Kong: a review. Proc Symp Hydraulics Hong Kong Waters, Hong Kong, 28-29 November 1995. Civil Engineering Office/Department, Hong Kong SAR Government, Hong Kong, p 343-360

Smetacek V, Bathmann U, Nothig EM, Scharek R (1991) Coastal eutrophication: causes and consequences. In: Manoura RCF, Martin JM, Wollast R (eds) Ocean margin processes in global change. John Wiley \& Sons, Chichester, p 251-279

Ward LG, Twilley RR (1986) Seasonal distributions of suspended particulate material and dissolved nutrients in a coastal plain estuary. Estuaries 9:156-168 
Watts JCD (1973) Further observation on the hydrology of the Hong Kong territorial waters. Hong Kong Fisheries Bulletin 3:9-35

Welsh BL, Eller FC (1991) Mechanisms controlling summertime oxygen depletion in western Long Island Sound. Estuaries 14:265-278

Yin K, Harrison PJ, St. John MA, Beamish RJ (1997) Effects of a fluctuation in Fraser River discharge on primary production in the central Strait of Georgia, British Columbia, Canada. Can J Fish Aquat Sci 54:1015-1024

Yin K, Harrison PJ, Chen J, Huang W, Qian PY (1999) Red tides during spring 1998 in Hong Kong: is El Niño responsible? Mar Ecol Prog Ser 187:289-294

Yin K, Qian PY, Chen JC, Hsieh DPH, Harrison PJ (2000) Dynamics of nutrients and phytoplankton biomass in the

Editorial responsibility: Otto Kinne (Editor), Oldendorf/Luhe, Germany
Pearl River estuary and adjacent waters of Hong Kong during summer: preliminary evidence for phosphorus and silicon limitation. Mar Ecol Prog Ser 194:295-305

Yin K, Qian PY, Wu MCS, Chen JC, Huang LM, Song XY, Jian WJ (2001) Shift from P to N limitation of phytoplankton biomass across the Pearl River estuarine Plume during summer. Mar Ecol Prog Ser 221:17-28

Zar JH (1999) Biostatistical analysis, 4th edn. Prentice-Hall, New York

Zhang J, Yu ZG, Wang JT, Ren JL, Chen HT, Xiong H, Dong LX, Xu WY (1999) The subtropical Zhujiang (Pearl River) estuary: nutrient, trace species and their relationship to photosynthesis. Estuar Coast Shelf Sci 49:385-400

Zhao H (1990) Evolution of the Pearl River estuary. Ocean Press, Beijing (in Chinese)

Submitted: December 18, 2000; Accepted: August 29, 2002 Proofs received from author(s): November 25, 2002 